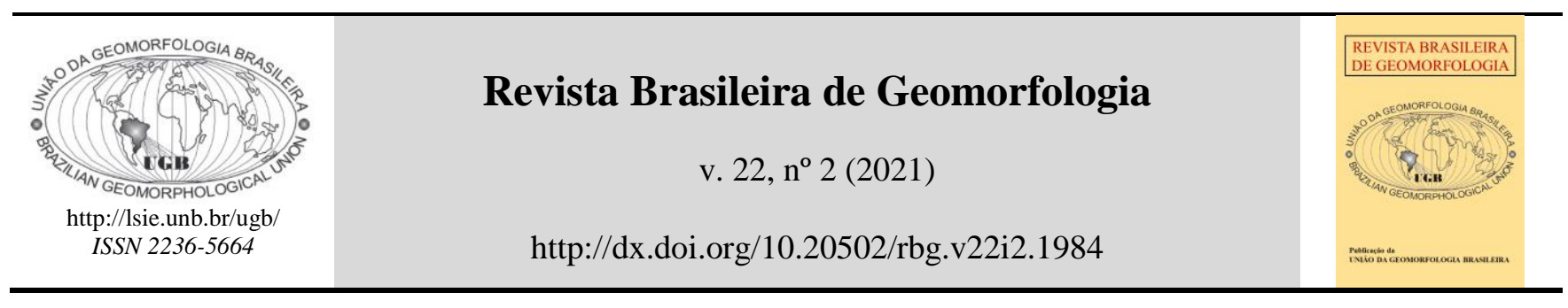

Nota técnica

\title{
Woody debris characterization in a small basin with araucaria forest
}

\section{Caracterização dos detritos lenhosos em uma pequena bacia com floresta de araucária}

\section{Karla Campagnolo ${ }^{1}$ e Masato Kobiyama ${ }^{2}$}

1 Federal University of Rio Grande do Sul, Hydraulic Research Institute, Porto Alegre, Brazil. karlac@ufrgs.br. ORCID: https://orcid.org/0000-0001-7653-8198

2 Federal University of Rio Grande do Sul, Department of Hydraulic Works, Porto Alegre, Brazil. masato.kobiyama@ufrgs.br.

ORCID: https://orcid.org/0000-0003-0615-9867

Recebido: 12/07/2020; Aceito: 01/12/2020; Publicado: 10/04/2021

\begin{abstract}
The effect that wood deposited in a river, woody debris (WD), causes on its hydrogeomorphic processes depends on the dimensions of the wood and the channel. Studies related to WD are still very rare in Brazil. Therefore, the objective of the present study was to demonstrate the feasible methodology of field survey and to characterize the WD along a natural channel inside the Perdizes stream basin, located in the municipality of Cambará do Sul, Rio Grande do Sul state. The study basin is characterized by the Mixed Rain Forest (Araucaria Forest), in a good condition of conservation. The final part of the stream, from its mouth, was divided into 3 sections. The WD field survey within these sections included orientation against the channel, size, origin and location. A topographic survey was carried out to construct the stream longitudinal profile. The results show that the volume and frequency of WD are directly related to the presence of araucaria in riparian vegetation. The total WD-quantity was compared with other rivers around the world. Furthermore, it was observed that the highest proportion of WD was oriented parallel to the flow direction, confirming an already known trend. In addition, the obtained results permit to say that the present methodology of field survey and of statistical analysis is useful for the DW dynamics study.
\end{abstract}

Keywords: Forest hydrology; Riparian vegetation; Fluvial geomorphology.

Resumo: O efeito que a madeira depositada em um rio, detritos lenhosos (WD), causa nos seus processos hidrogeomorfológicos depende das dimensões da madeira e do canal. Estudos sobre WD são muito poucos no Brasil. Portanto, o objetivo do presente trabalho foi demonstrar a metodologia viável de pesquisa de campo e caracterizar a DL ao longo de um canal natural na bacia do arroio Perdizes, localizado no município de Cambará do Sul (RS). A bacia de estudo é caracterizada com a Floresta Ombrófila Mista (Floresta de Araucária), em bom estado de conservação. A parte final do arroio, a partir da sua foz, foi dividida em 3 trechos. O levantamento em campo dos WD incluiu orientação no canal, tamanho, origem e localização. Em relação ao arroio, foi realizado levantamento topográfico. Os resultados mostram que o volume e a frequência dos WD estão diretamente relacionados à presença de araucárias na vegetação ripária. A quantidade total de WD foi comparada com outros rios em outros países. Observou-se que a maior proporção de WD estava orientada paralelamente à direção do fluxo, confirmando uma tendência já conhecida. Além disso, os resultados obtidos mostraram que a presente metodologia de pesquisa de campo e de análise estatística é útil para o estudo da dinâmica de WD.

Palavra-chave: Hidrologia florestal ; Vegetação ripária; Geomorfologia fluvial. 


\section{Introduction}

The rivers and their flood plains, which are both closely associated, represent corridors of extraordinarily ecological, environmental, social, cultural and economic value (ANDREOLI et al., 2012). These corridors are also called riparian zones, an area considered as an ecotone between terrestrial and aquatic ecosystems (KOBIYAMA, 2003).

In these places, there is normally riparian vegetation. The preservation of these vegetated corridors has been discussed all over the world. Paola (2011) made a pertinent observation of the relationship between vegetation and the river. The author emphasized that rivers should be seen literally as living beings, so that their ecosystems are intertwined with their respective processes. Ecological processes of trees, shrubs and grasses and hydrogeomorphological processes interact and also depend on one another in complex ways. Each ecosystem has its own characteristics, where several factors control the ecological equilibrium. One of such factors is the vegetation density, which, according to Stoffel and Wilford (2012), controls the vitality, the number of species and age distribution of riparian vegetation.

Riparian vegetation and hydrogeomorphological processes are strongly connected in a basin. Eaton et al. (2012) highlighted that more satisfactory understanding of these processes that control channel morphology is an important objective of fluvial geomorphology. Among these processes, the production, transport and storage of woody debris (WD), or Large Wood (LW), which is plant material such as branches and trunks, are very significant (NAKAMURA; SWANSON, 1994). Such processes take place from the riparian corridor to the riverbed.

The WD presence is a common feature in drainage networks in forest basins around the world. However, Comiti et al. (2006) observed that only in headwater regions of relatively intact forest mountains these woody materials can be found abundantly. It is due to the massive deforestation that has been occurring for centuries on accessible hillslopes and floodplains. This situation is particularly common in developing countries that keep native forests only in the headwaters where conditions for human activities, such as agriculture are less favorable (COMITI et al., 2006). Furthermore, a large landslide near drainage networks generates a lot of WD which can flow into a downstream river, which modifies fluvial landforms (RUIZ-VILLANUEVA et al., 2014; CHAITHONG et al., 2018).

When the WD contributes to accumulations in the mountainous river channel, they act in the formation of step-pool and riffle-pool, which are a kind of geomorphological system (HOGAN; LUZI, 2010). Consequently, the WD presence increases the resistance to flow and stores a large volume of sediment (COMITI et al., 2008). These morphological effects vary considerably depending on the degree of forest disturbance and the basin anthropization.

In addition, the use of wood and WD is a widespread low-cost technique for restoring river environments. For example, in Brazil, Fernandez et al. (2010) set up wooden stakes in stream channels in western Paraná state, and Pinto, Agra e Furley (2017) carried out similar work in the Mangaraí River, Espírito Santo state. The second authors reported that the use of eucalyptus trunks was a good alternative for exercising fluvial restoration techniques, and showed rapid and positive results in terms of channel morphology and fish abundance. Given the relatively small amount of financial resources currently available for river recovery and the wide range of degradation, it can be inferred that only a simple and low-cost approach would be feasible, such as the use of woody materials (PASTERNACK, 2013).

Brooks (2006) pointed out that in the state of New South Wales (Australia), the WD removal from rivers is listed in fisheries legislation as a threatening process. In this case, a threatening process is defined as a process that threatens, or may threaten, the survival or evolutionary development of a species, population or ecological fish community.

In various countries, technical manuals that seek to didactically clarify the role of wood in the river ecosystem have been published. For example, Schuett-Hames et al. (1999), Giordanengo et al. (2016), and USBR; ERDC (2016). These manuals highlighted that the allochthonous plant material provides fluvial structures at various spatial-scales, nutrients (by decomposition) and habitat for aquatic species. These are the main ecological implications provided by WD. The manuals result from many scientific and technical works on WD, and guide works in various fields of study.

On the other hand, studies related to WD are rare in the Brazilian scenario (BINDA; FERNANDEZ, 2011; CAMPAGNOLO; KOBIYAMA; FAN, 2020). In Brazil, there is a great diversity of ecosystems. Each of them has 
the potential to supply different volumes of WD with different susceptibilities to decomposition, and consequently determines different fluvial structures and permanent times of accumulations. Such a variety of situations requires more studies of WD dynamics along the rivers.

The WD is a vital natural component of watercourses. However, the traditional management carried out in Brazil often has aimed to remove it from the river system. According to Comiti et al. (2011), this social activity has already occurred in Italy, where the increasing presence of WD in rivers has led managers to suppress riparian forests, so they removed logs from the channels. The authors mentioned that such activities had been carried out without scientific approach and that their economic justification (cost-benefit balance) was debatable. The same consideration must be put in Brazilian cases.

Understanding of the WD dynamics is essential in riparian forest management (GRAHAM et al., 1994; RIFFELL et al., 2011). Therefore, its scientific and technical information also becomes an essential issue for biological conservation within the forest ecosystems (MORRISSEY; JENKINS; SAUNDERS, 2014). Moreover, such dynamics can be encountered in the two principal components in a basin: river channels and hillslope sites. Thus, for any community working in an integrated management of basin, water resources and forest resources, the information on WD is very important.

Upon concluding a review of the occurrence of debris flow and its scientific studies in Brazil, Kobiyama, Michel e Goerl (2019) suggested five urgent actions for Brazilian organizations, one of which is further research on the WD flow dynamics. Hence, knowledge of the WD characteristics along the river channels is essential.

In this way, the objective of the present study was to present the methodology of field survey and to characterize the WD in a natural channel located in the municipality of Cambará do Sul, Rio Grande do Sul state. A demonstration of results obtained through the field survey certainly confirms that the present methodology is easily feasible. Furthermore, such a study does not exist in regions characterized with Araucaria Forest. Therefore, the obtained results can be of national importance. To check whether these results are peculiar or not, they were compared to other studies in the world.

\section{Material and Methods}

\subsection{Study area}

The present study was developed within the Perdizes stream basin $\left(15.24 \mathrm{~km}^{2}\right)$ which is located in the municipality of Cambará do Sul (Figure 1). This basin is a part of the Aparados da Serra National Park (PNAS), and the studied section is close to the Itaimbezinho canyon and the administrative headquarters of the PNAS. This region is inserted in the Atlantic Forest biome, with an average altitude of $920 \mathrm{~m}$.
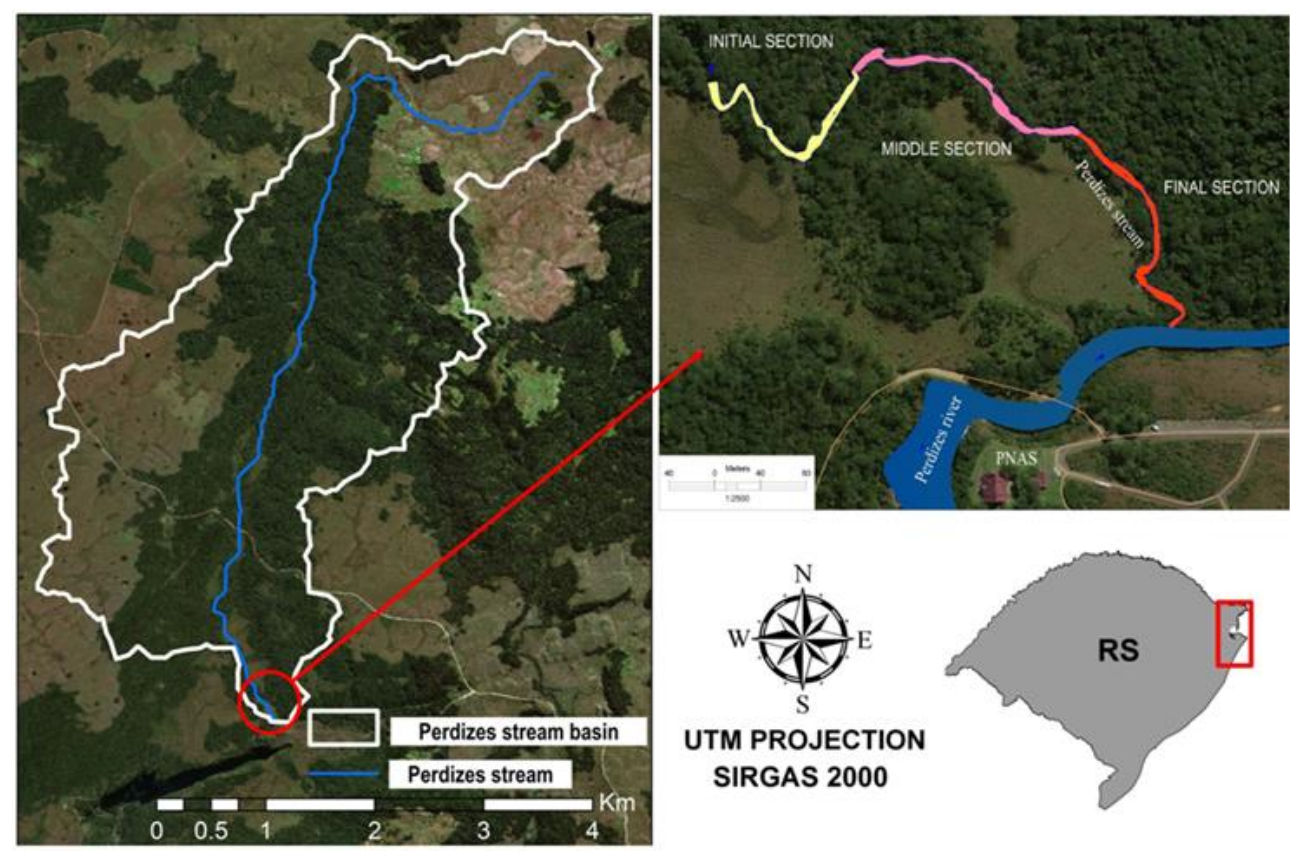

Figure 1. Study area: Perdizes stream basin and three analyzed sections. 
Because of the PNAS, Cambará do Sul receives many tourists who want to see the natural beauty mainly with canyons. According to its official management plan (IBAMA, 2004), in the PNAS the forest fields and formations close to the Itaimbezinho canyon show regular environmental integrity, probably due to disturbances from public visitation and use as well as the occupation of areas with livestock (areas not expropriated by the federal government).

The upper part of the Perdizes stream basin is characterized with a physiognomy naturally marked by a mosaic of grass and forest. The dominant substrate in the channel is pebbles, with the stream having an average width of $8 \mathrm{~m}$. The main forest formation in the region corresponds to the Mixed Rain Forest, also called Araucaria Forest. The "mixed" nomenclature results from the association between coniferous and deciduous trees. It must be noted that, in Brazil, only three species of native coniferous are encountered: Araucaria angustifolia (araucaria), Podocarpus lambertii (pinheiro-bravo) and Podocarpus sellowii (pinho-bravo). Because of the geographical and climatic conditions, this forest formation has unique characteristics in the PNAS region, and this forest is preserved and also related to the richness of existing epiphytes (IBAMA, 2004). Santos et al. (2015) highlighted that the forest in the PNAS is characterized with the emerging crowns of the araucaria, and confirmed that the canopy is formed mainly by species of Myrtaceae, Lauraceae and Aquifoliaceae. Furthermore, Bergamin (2010) pointed out that the Podocarpus lambertii is scarce.

Based on the Köppen System classification, the region's climate is defined as Cfb: humid subtropical with no defined dry season, with mild summer. The mean annual temperature is $14.8 \mathrm{oC}$, the mean annual rainfall is 1,787 $\mathrm{mm}$ and the relative humidity is around $80 \%$ (MORENO, 1961).

According to the Environmental Information Database (BDiA) of the Brazilian Institute of Geography and Statistics - IBGE, the Perdizes stream basin is covered predominantly by the aluminum humic cambisols (IBGE, 2020). This soil type is poorly developed and presents low permeability, being normally associated with gentle and/or mountainous reliefs (EMBRAPA, 2018).

\subsection{Data collection and analysis}

The topographic survey was carried out by using Topcon@ $\odot$ total station model CTS3007 in the channel with about $770 \mathrm{~m}$ along the Perdizes stream, from its mouth (SIRGAS 2000 Datum, $-29.157339^{\circ} \mathrm{S}-50.077713^{\circ} \mathrm{W}$ ). Then it was divided into 3 sections: initial section, middle section and final section (Figure 1).

The WD volume survey in the section was carried out in July 2019, where all the pieces of wood with more than $7.0 \mathrm{~cm}$ in diameter and $1.0 \mathrm{~m}$ in length were measured. This measurement criterion with size is common among scientists who studied the WD dynamics in the channel, for example, Abbe and Montgomery (2003), Andreoli et al. (2007), Comiti et al. (2008), and Galia et al. (2018). According to these authors, this criterion was considered adequate to represent the WD characteristics in relation to the channel dimensions. The WD measurements were performed with forest suture and measuring tape (Figure 2). Here it should be mentioned that this debris was not removed from the measurement site.

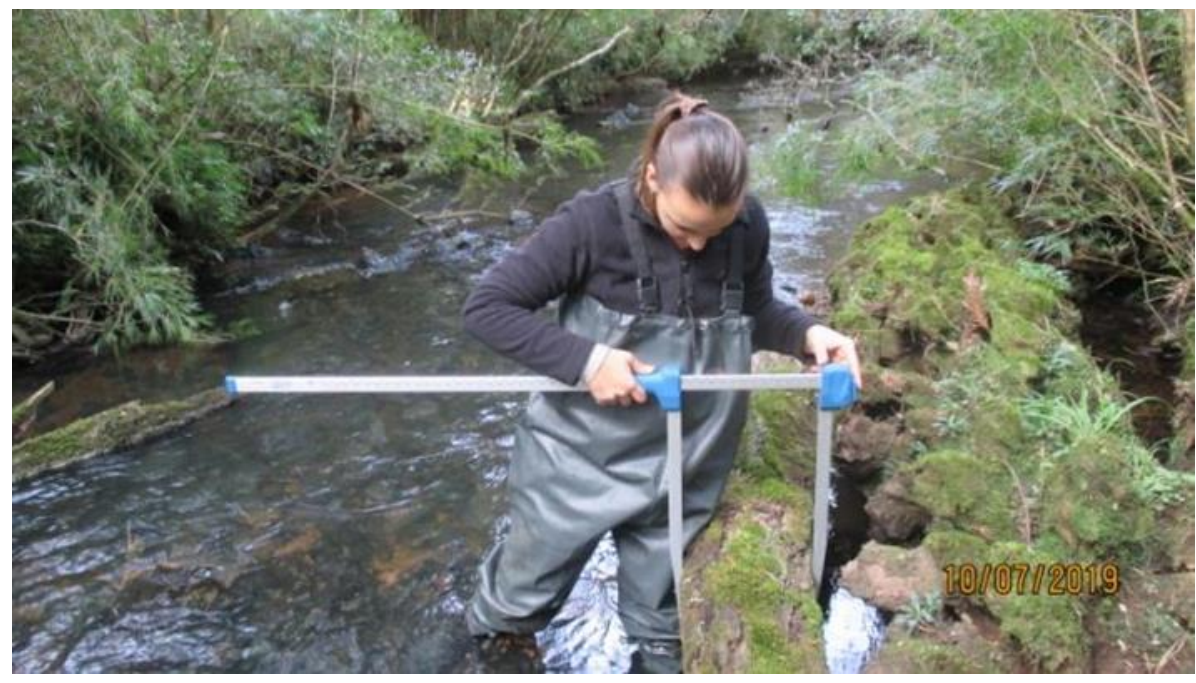

Figure 2. Measurement of diameter of woody debris with forest suture. 
At the moment of measurement, the origin of the wood deposited in the channel was identified as coniferous (in the case of the study basin, araucaria) or deciduous, as Galia et al. (2018) also did. In ecosystems such as the Mixed Rain forest, coniferous trees are considered key species. It is emphasized that, in the study area, there is a marked presence of araucaria (Figure 3).

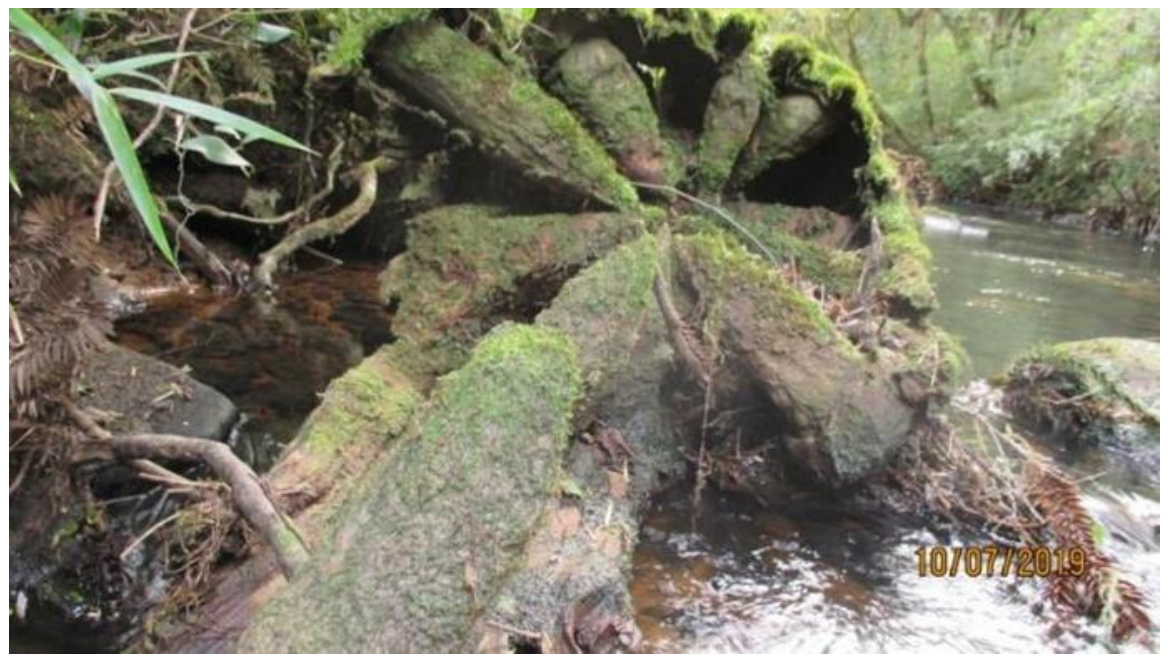

Figure 3. Woody debris of araucaria in the Perdizes stream.

The volume of each wood fragment (V) was calculated from its maximum diameter, applying a form factor and assuming a solid cylindrical shape, as is commonly done in forest inventories:

$$
V=L \cdot\left[\left(d^{2} \cdot \pi\right) / 4\right] \cdot f
$$

where $L$ is the WD length (m); $d$ is the WD diameter $(\mathrm{m})$; and $f$ is the form factor $(=0.7)$.

The spatial abundance of WD along the river channel in terms of volume $\left(\mathrm{m}^{3} /\right.$ river section) and the number of elements (parts/river section) were calculated.

The orientation of individual WD in relation to flow was also measured. Then the orientation was classified into four types: parallel, perpendicular, and two kinds of oblique (Figure 4), similarly to the classification used by Magilligan et al. (2008). In this type of classification, the orientation is numbered, where the Orientation 1 is parallel to the flow, regardless of the orientation of the roots; the Orientation 2 is perpendicular to the flow; and the Orientation 3 is oblique to the flow, with the roots oriented upstream, meanwhile the Orientation 4 is oblique with the roots oriented downstream.

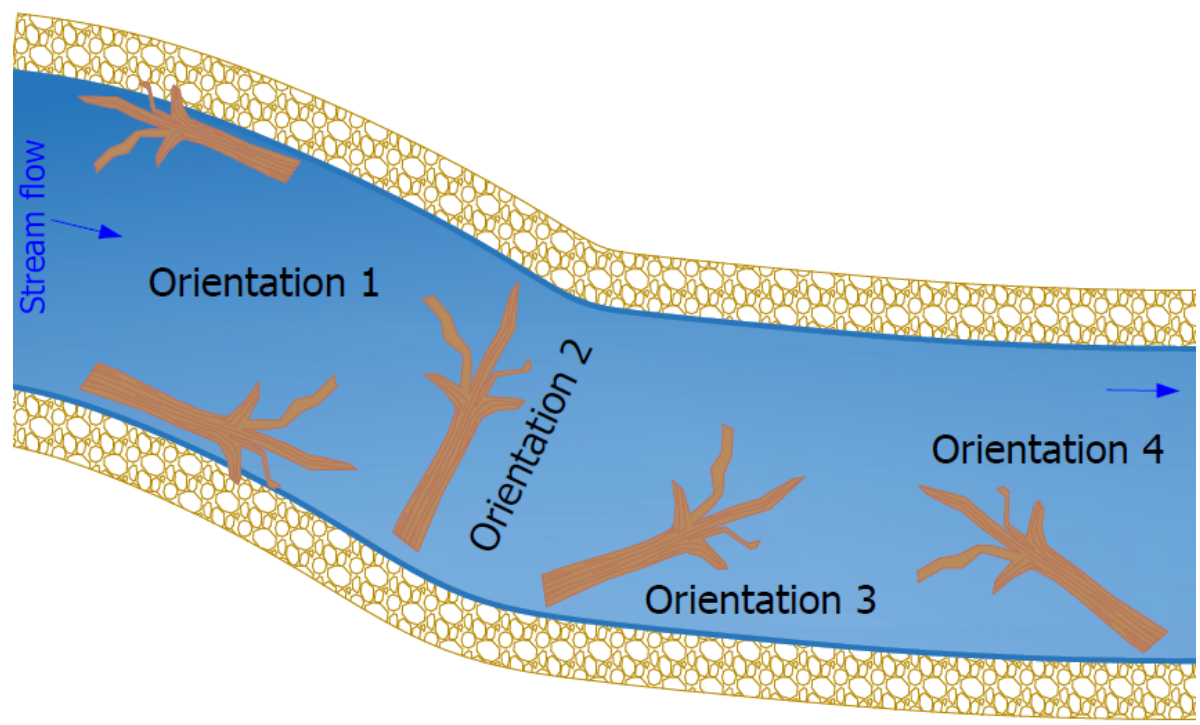

Figure 4. Orientation categories of woody debris in the stream. 
The sinuosity of the section $(S)$ was determined with:

$$
S=\frac{L t}{L v}
$$

where $L t$ is the actual length of the section (m); and $L v$ is the straight line length (m).

Pearson's Correlation coefficient (r) was used to analyze the correlation between the characteristics of the river and the WD found within the channel. Its value varies from -1 to +1 .

\section{Results and discussion}

From the topographic survey, the longitudinal profile of the study stream was generated with high precision (Figure 5). The stream has a steeper course near its mouth. Table 1 demonstrates the summary of some parameters of three stream-sections and WD, obtained with the topographic survey.

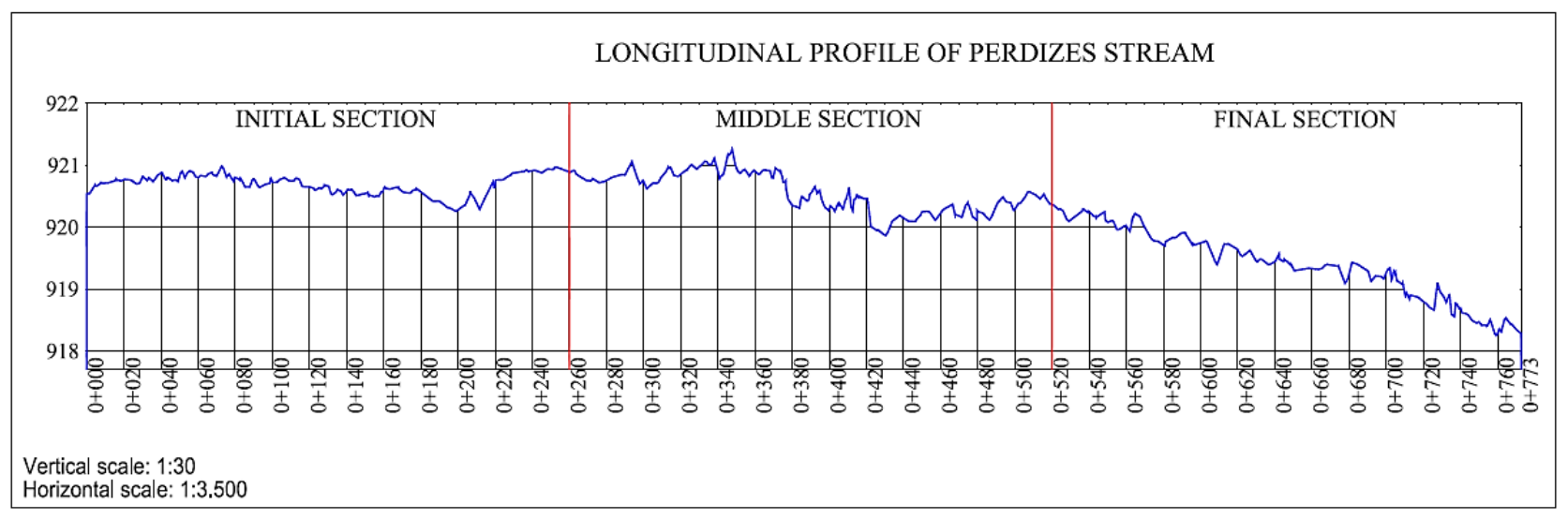

Figure 5. Longitudinal profile of an analyzed stretch of about 770 meters in the Perdizes stream.

Table 1. Field survey information along the Perdizes stream: (a) Stream section characteristics; and (b) woody debris characteristic.

\begin{tabular}{|c|c|c|c|c|c|c|c|}
\hline \multicolumn{4}{|c|}{ (a) } & \multicolumn{4}{|c|}{ (b) } \\
\hline & $\begin{array}{l}\text { Initial } \\
\text { section }\end{array}$ & $\begin{array}{l}\text { Middle } \\
\text { section }\end{array}$ & $\begin{array}{l}\text { Final } \\
\text { section }\end{array}$ & & $\begin{array}{l}\text { Initial } \\
\text { section }\end{array}$ & $\begin{array}{l}\text { Middle } \\
\text { section }\end{array}$ & $\begin{array}{l}\text { Final } \\
\text { section }\end{array}$ \\
\hline $\begin{array}{l}\text { Stream section } \\
\text { length }(\mathrm{m})\end{array}$ & 260 & 260 & 255 & $\begin{array}{l}\text { Abundance (number of } \\
\text { pieces } / \mathrm{m} \text { ) }\end{array}$ & 0.17 & 0.26 & 0.17 \\
\hline $\begin{array}{l}\text { Mean slope } \\
(\%)\end{array}$ & 0.28 & 0.54 & 0.84 & Mean diameter $(\mathrm{m})^{*}$ & 0.19 & 0.19 & 0.21 \\
\hline \multirow[t]{4}{*}{$\begin{array}{l}\text { Sinuosity } \\
(\mathrm{m} / \mathrm{m})\end{array}$} & \multirow[t]{4}{*}{1.82} & \multirow[t]{4}{*}{1.13} & \multirow[t]{4}{*}{1.24} & Mean length $(\mathrm{m})^{*}$ & 3.65 & 3.02 & 3.33 \\
\hline & & & & Total volume ( $\mathrm{m}^{3} /$ section) & 4,66 & 7,14 & 6,09 \\
\hline & & & & Coniferous & 20.5 & 22.1 & 23.3 \\
\hline & & & & Deciduous & 79.5 & 77.9 & 76.7 \\
\hline
\end{tabular}

*there was no statistical difference between the means of diameter and length.

A total of 155 pieces of WD were identified and characterized within $770 \mathrm{~m}$ of a stream stretch. The WD was more abundant in the middle section whose mean slope is $0.54 \%$, totaling $7.14 \mathrm{~m}^{3}$ of material (about $40 \%$ of the total) (Table 1). In addition, $17 \%$ of all WDs were at least $5 \mathrm{~m}$ long. Regarding the WD measured and disposed perpendicular to the flow, it was observed that the materials had a mean size of $0.16 \mathrm{~m} \times 2.92 \mathrm{~m}$ (diameter $\times$ length). The frequency distribution of diameter and length measurements WD can be observed in Figure 6. survey. araucaria (Figure 3). 


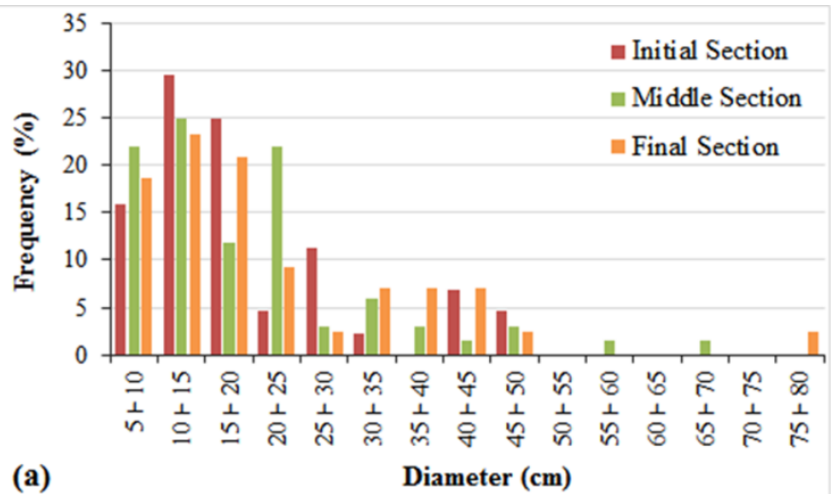

(a)

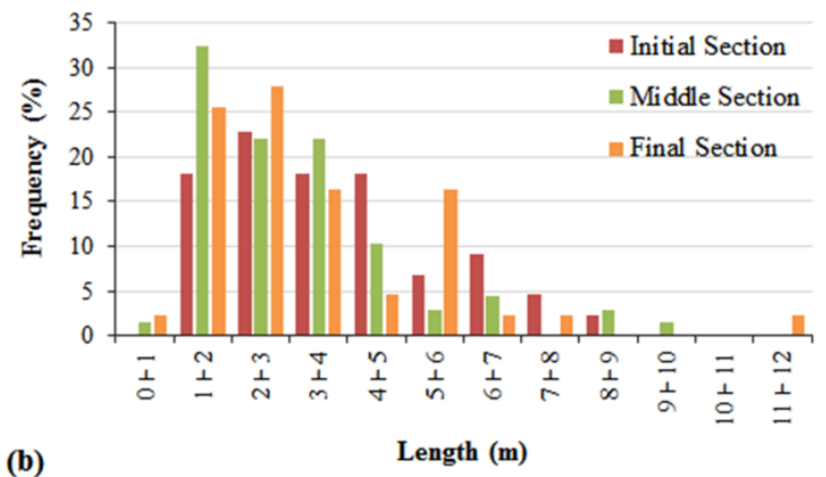

(b)

Figure 6. Frequency distribution of WD: (a) diameters; and (b) lengths.

The sections have a similar distribution approximately, which is the same way that Martin, Pavlowsky e Harden (2016) inventoried WD along nine reaches of the Big River, Midwestern USA. Wohl et al (2011) and Martin, Pavlowsky e Harden (2016) analyzed the average wood piece diameter and length in two American forested basins, and demonstrated that the physical dimensions of WD in old-growth forests are, in general, smaller compared to those in younger forests, even considering that river systems in different regions possess different species and ecosystems. According to these authors, it occurs due to different recruitment processes, mainly related to the erosion of the margins, in young forests, and the mortality of trees, in old forests. Still, older and larger trees in ancient forests are more likely to contribute small pieces because of the wind.

The total volume of wood $\left(\mathrm{m}^{3} /\right.$ river section) showed a strong positive correlation $(\mathrm{r}=0.93)$ with the mean slope $(\%)$, and a strong negative correlation $(-0.96)$ with the sinuosity $(\mathrm{m} / \mathrm{m})$. The abundance of wood $\left(\mathrm{n}^{\circ}\right.$ pieces/meter) per section presented a negative correlation (-0.62) for sinuosity and a strong positive correlation with the channel slope (0.97) (Table 2). According to the results, the mean slope of the section was not a determinant factor of WD abundance. On statistical base, the mean diameter and the mean length of the pieces were not different among three sections (Table 1).

Table 2. Pearson's correlation coefficient ( $\mathrm{r}$ ) between characteristics of sections and woody debris variables.

\begin{tabular}{lcc}
\hline \multicolumn{1}{c}{ Stream characteristic } & \multicolumn{2}{c}{ Woody debris variables } \\
& $\begin{array}{c}\text { Total volume } \\
\left(\mathrm{m}^{3} / \text { section }\right)\end{array}$ & $\begin{array}{c}\text { Abundance } \\
\text { (number of pieces/meter) }\end{array}$ \\
\hline Slope & 0.93 & $0.97 *$ \\
Sinuosity & $-0.96^{*}$ & -0.62 \\
\hline
\end{tabular}

Comparing the results of Magilligan et al. (2008) that measured the WD dimensions in some rivers with width from 10 to $54 \mathrm{~m}$, in the USA, it is noted that their results of mean length were larger than those of the present study meanwhile their mean diameters were similar to those of the present study. Since the studied sections of the Perdizes stream have an average width of $8 \mathrm{~m}$, it can be thought that the stream width may influence the mean length of WD.

Analyzing WD ( $d>20 \mathrm{~mm}$ and $L>0.6 \mathrm{~m})$ in stretches of a lowland river in the UK, with the basin area and flow similar to the Perdizes stream, Blaen et al. (2018) observed that the greater the sinuosity, the larger quantity of WD. The same result did not occur in case of the Perdizes stream. It implies that there is no simple relation between the hydrogeomorphological processes in river and WD dynamics. 
Relative to the origin of the debris, the relevance of the Araucaria could also be confirmed in the WD supply to the stream, because more than $20 \%$ of all WDs encountered in the channel were identified as this species. It was observed that there is a predominance of WD of Araucaria in the pools along the stream. This is probably due to the high density of this wood and also its high resistance against rot. According to Haga et al. (2017) that investigated the effect of small wood on large ones along streams, different tree species have different decay-rates of wood, and contribute to the variation of basic density of WD in each depositional environment. Thus, peculiar characteristics of Araucaria would be necessarily investigated in future.

Figure 7 demonstrates an overview of the study site and the spatial distribution of WDs along the three sections. Parallel orientation was found most frequently (more than $60 \%$ in all the sections) during the survey (Figure 8). It is probably because this orientation is more stable in the system. Martin, Pavlowsky e Harden (2016) also reported that more than half (56\%) of the WD pieces surveyed in the Big River were oriented parallel to the direction of flow, too. However, there is a different report, for example, Baillie and Davies (2002) that analyzed native streams in New Zealand and observed that most of the WD was perpendicular to the flow.

Furthermore, according to Magilligan et al. (2008), the orientation controls the potential for convergence and divergence of the flow, and consequently the formation of pools and sediment storage places. In analyzing basins in the coast of Maine, the authors observed that the dominant WD orientations, regardless of basin size, are parallel or oblique to the flow. Considering the hazard assessment, Wohl et al. (2016) pointed out that the orientation of wood influences its ability to act as a strainer or to snag floating objects, and that it substantially influences hazards. Therefore, it can be said that the WD orientation should be studied more at each fluvial condition.

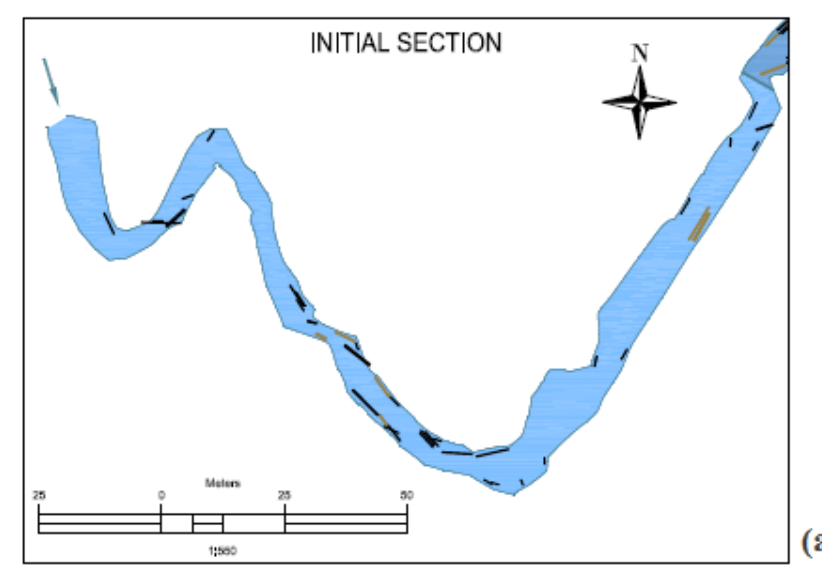

(a)

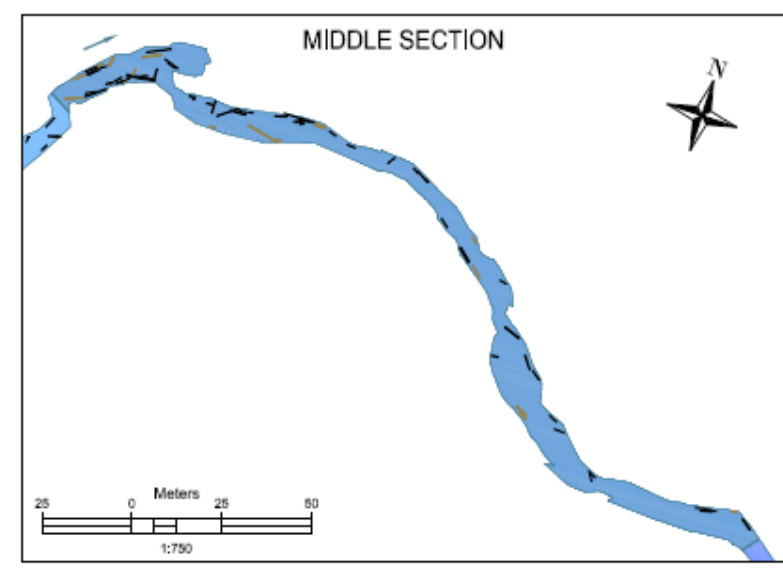

(b)

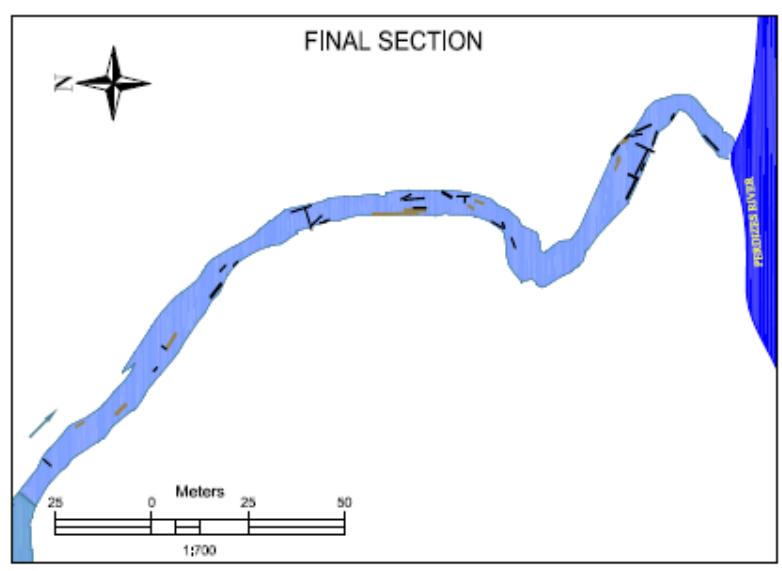

(c)

Figure 7. Spatial distribution of woody debris along the stream: (a) initial section; (b) middle section; and (c) final section. 

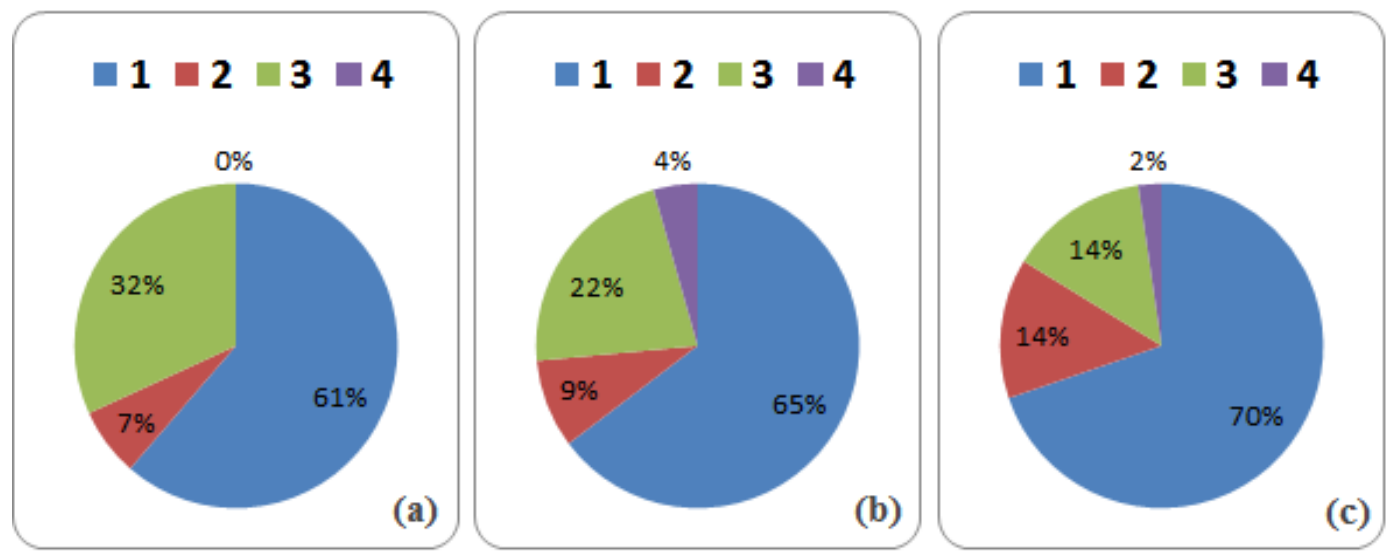

Figure 8. WD orientation: (a) Initial section; (b) middle section; and (c) final section. The orientation of each category is shown in Fig. 4.

During the field survey, it was clearly observed that the composition of tree species in the riparian zone directly affects the volume of WD in the stream channel in headwater regions. The presence of araucaria (conifer) was a relevant variable for the total volume of WD, with the mean value of approximately $22 \%$, which is larger than its presence among live trees. Galia et al. (2018) in a similar study concluded that coniferous trees tend to provide larger WD (usually whole trees).

One of the most important topics related to the WD study might be the "woody debris budget", investigated by Benda et al. $(2002,2003)$ and Benda and Bigelow (2014). It consists of making an inventory of the supply of WD to the river by factors that include the forest dynamics (natural mortality), hillslope dynamics (mass movements and soil erosion) and river network dynamics (supply of wood and other sediments). In case of just sediment, the concept of budget together with routing has been intensively and widely investigated since Dietrich and Dunne (1978). However, the case of WD, i.e., woody debris budget and routing is still very scarce. This investigation is only possible with a long-period continuous monitoring system.

To define which size can be efficient for stabilizing the WD in terms of orientation, further measurements will be necessary, especially after strong rainfall events.

\section{Conclusions}

An environmentally-sustainable future is widely desired by all the society. Therefore, it is extremely important that Brazilian scientists provide technical and scientific support to guide the comprehensive management of forest-river ecosystems, i.e., riparian ecosystems. In this circumstance, through a detailed survey of the WD encountered within the Perdizes stream (RS), it can be concluded that the riparian vegetation provides a large volume of WD for the fluvial ecosystem $\left(17.9 \mathrm{~m}^{3} / 770 \mathrm{~m}\right)$. Furthermore, it could be shown that the present methodology of field survey and of statistical analysis is useful and feasible for the DW dynamics study.

As a suggestion for future studies, the WD distribution must be related to the hydrodynamic features (discharge, velocity and depth) of the stream, in addition to sediment sizes distribution on the channel-bed. This type of hydrogeomorphic investigation will allow better understanding the WD distribution in the stream channel.

Finally, the importance of riparian vegetation, living and standing as well as dead and deposited on streambed and forest floor, should be emphasized not only in the scientific community, but also in the local community responsible for basins management. 
Authors' Contributions: Karla Campagnolo collected the data, did the data analysis, and wrote the paper; Masato Kobiyama collected the data, reviewed and edited the manuscript. The authors read and approved the final manuscript.

Financing: This research was partially supported by the Brazilian agencies CAPES and ANA (grant numbers 16/2017).

Acknowledgment: The authors would like to thank the staff at the Aparados da Serra National Park office of ICMBio for the logistic support for the present study.

Conflict of Interest: The authors declare no conflict of interest, and the funders had no interference in the development of the study; in the collection, analysis, or interpretation of data; in the writing of the manuscript, or in the decision to publish the results.

\section{References}

1. ABBE, T. B.; MONTGOMERY, D. R. Patterns and processes of wood debris accumulation in the Queets river basin, Washington. Geomorphology, v. 51, n. 1-3, p. 81-107, 2003.

2. ANDREOLI, A.; COMITI, F.; LENZI, M.A. Characteristics, distribution and geomorphic role of large woody debris in a mountain stream of the Chilean Andes. Earth Surf. Process. Landforms, v. 32, p. 1675-1692, 2007. DOI: 10.1002/esp.1593

3. ANDREOLI, A.; MAO, L.; IROUMÉ, A.; ARUMÍ, J.L.; NARDINI, A.; PIZARRO, R.; CAAMAÑO, D.; MEIER, C.; LINK, O. The need for a hydromorphological approach to Chilean river management. Revista Chilena de História Natural, v. 85, n. 3, p. 339-43, 2012. DOI: 10.4067/S0716-078X2012000300008

4. BAILLIE, B.R.; DAVIES, T. R. Influence of large woody debris on channel morphology in native forest and pine plantation streams in the Nelson region, New Zealand. New Zealand Journal of Marine and Freshwater Research, v. 36, n. 4, p. 763-74, 2002. DOI: 10.1080/00288330.2002.9517129

5. BENDA, L.E.; BIGELOW, P.; WORSLEY, T.M. Recruitment of wood to streams in old-growth and second-growth redwood forests, northern California, U.S.A. Canadian Journal of Forest Research, v. 32, n. 8, p. 1460-1477, 2002. DOI: 10.1139/x02-065

6. BENDA, L.; MILLER, D.; SIAS, J.; MARTIN, D.; BILBY, R.; VELDHUISEN, C.; DUNNE, T. Wood recruitment processes and wood budgeting. American Fisheries Society Symposium, v. 37, p. 49-73, 2003.

7. BENDA, L.; BIGELOW, P. On the patterns and processes of wood in northern California streams. Geomorphology, v. 209, p. 79-97, 2014. DOI: 10.1016/j.geomorph.2013.11.028

8. BERGAMIN, R.S. Especificidade de espécies arbóreas no Sudeste da Mata Atlântica e padrões de diversidade em florestas com araucária. Dissertação (Mestrado em Ciências - ênfase em Ecologia) - Instituto de Biociência, Universidade Federal do Rio Grande do Sul, Porto Alegre. 2010. 76p.

9. BINDA, A.L.; FERNANDEZ, O. V. Q. Morfologia de leito e processos erosivo-deposicionais em áreas afetadas por acumulações de detritos lenhosos: rio Guabiroba, Guarapuava/PR. Revista Brasileira de Geomorfologia, v. 12, n. 2, p. 105-15, 2011. DOI: 10.20502/rbg.v12i2.239

10. BLAEN, P.J.; KURZ, M.J.; DRUMMOND, J.D.; KNAPP, J.L.A.; MENDOZA-LERA, C.; SCHMADEL, N.M.; KLAAR, M.J.; JÄGER, A.; FOLEGOT, S.; LEE-CULLIN, J.; WARD, A.S.; ZARNETSKE, J.P.; DATRY, T.; MILNER, A.M.; LEWANDOWSKI, J.; HANNAH, D.M.; KRAUSE, S. Woody debris is related to reach-scale hotspots of lowland stream ecosystem respiration under baseflow conditions. Ecohydrology, v. 11, n. 5, p. 1-9, 2018. DOI: 10.1002/eco.1952

11. BROOKS, A. P. Design guideline for the reintroduction of wood into Australian streams. Report for Land \& Water Australia, 2006. 85p. Available from: http://lwa.gov.au/products/px061171

12. COMITI, F.; ANDREOLI, A.; LENZI, M. A.; MAO, L. Spatial density and characteristics of woody debris in five mountain rivers of the Dolomites (Italian Alps). Geomorphology, v. 78, n. 1-2, p. 44-63, 2006. DOI: 10.1016/j.geomorph.2006.01.021

13. COMITI, F.; ANDREOLI, A.; MAO, L.; LENZI, M.A. Wood storage in three mountain streams of the Southern Andes and its hydro-morphological effects. Earth Surface Processes and Landforms, v. 33, p. 244-262, 2008. DOI: 10.1002/esp.1541

14. COMITI, F.; CANAL, M.; SURIAN, N.; MAO, L.; PICCO, L.; LENZI, M.A. Channel adjustments and vegetation cover dynamics in a large gravel bed river over the last 200years. Geomorphology, v. 125, n. 1, p. 147-59, 2011. DOI: 10.1016/j.geomorph.2010.09.011

15. CAMPAGNOLO, K.; KOBIYAMA, M.; FAN, F. M. Panorama geral sobre estudos da influência dos detritos lenhosos na dinâmica de rios do mundo e do Brasil. Ciência e Natura, v.42, e62, 2020. DOI: 10.5902/2179460X39228

16. CHAITHONG, T.; KOMORI, D.; SUKEGAWA, Y.; ANZAI, S. Estimating woody debris recruitment in a stream caused by a typhoon-induced landslide: a case study of Typhoon Lionrock in Iwaizumi, Iwate prefecture, Japan. Geomatics, Natural Hazards and Risk, v.9, n.1, p. 1071-1084, 2018. DOI: 10.1080/19475705.2018.1490822

17. DIETRICH, W.E.; DUNNE, T. Sediment budget for a small catchment in mountainous terrain. Zeits. Geomorphol. N.F., v. 29, p. 191-206, 1978. 
18. EATON, B.C.; HASSAN, M.A.; DAVIDSON, S.L. Modeling wood dynamics, jam formation, and sediment storage in a gravel-bed stream. Journal of Geophysical Research: Earth Surface, v. 117, n. 4, p. 1-18, 2012. DOI: 10.1029/2012JF002385

19. EMBRAPA. Sistema Brasileiro de Classificação de Solos. Brasília: EMBRAPA, 2018.

20. FERNANDEZ, O. V. Q.; RAMOS, S. M.; WELTER, V.; BAGATINI, Y. M.; BENKE, C. D.; MÜNCHEN, F. Simulações de morfologia fluvial e recuperação de habitats aquáticos em córregos da região oeste do Paraná. Geografia, v. 27, n. 3, p. 81-95, 2010.

21. GALIA, T.; RUIZ-VILLANUEVA, V.; TICHAVSKÝ, R.; ŠILHÁN, K.; HORÁČEK, M.; STOFFEL, M. Characteristics and abundance of large and small instream wood in a Carpathian mixed-forest headwater basin. Forest Ecology and Management, v. 424, p. 468-82, 2018. DOI: 10.1016/j.foreco.2018.05.031

22. GIORDANENGO, J. H.; MANDEL, R. H.; SPITZ, W. J.; BOSSLER, M. C.; BLAZEWICZ, M. J.; YOCHUM, S. E.; JAGT, K. R.; LABARRE, W. J.; GURNEE, G. E.; HUMPHRIES, R.; UHING, K. T. Living Streambanks: A Manual of Bioengineering Treatments for Colorado Streams. AloTerra Restoration Services, LLC and Golder Associates. 2016. 160p.

23. GRAHAM, R. T.; HARVEY, A. E.; JURGENSEN, M. F.; JAIN, T. B.; TONN, J. R.; PAGE-DUMROESE, D. S. Managing coarse woody debris in forests of the Rocky Mountains. Res. Pap. INT-RP-477. Ogden, UT: U.S. Department of Agriculture, Forest Service, Intermountain Research Station. 1994. 12p.

24. HAGA, H.; MORIISHIDA, T.; MORISHITA, N.; FUJIMOTO, T. Properties of small instream wood as a logjam clogging agent: Implications for clogging dynamics based on wood density, water content, and depositional environment. Geomorphology, v. 296, p. 1-10, 2017. DOI: 10.1016/j.geomorph.2017.08.043

25. HOGAN, D. L.; LUZI, D. S. Channel Geomorphology: Fluvial Forms, Processes, and Forest Management Effects, In: Compendium of Forest Hydrology and Geomorphology in British Columbia, p. 331-371, 2010.

26. IBAMA (Instituto Brasileiro do Meio Ambiente e dos Recursos Naturais Renováveis). Plano de Manejo dos Parques Aparados da Serra e Serra Geral. Ministério do Meio Ambiente; Brasília. 2004.

27. IBGE (Instituto Brasileiro de Geografia e Estatística). Banco de dados de Informações Ambientais - Pedologia. 2020. $<$ https://bdiaweb.ibge.gov.br/\#/consulta/pedologia>. Access on 3 out. 2020.

28. KOBIYAMA, M. Conceitos de zona ripária e seus aspectos geobiohidrológicos. In: I Seminário de Hidrologia Florestal: Zonas Ripárias, 1., 2003, Alfredo Wagner. Anais... Florianópolis: UFSC/PPGEA. 2003. p. 1-13.

29. KOBIYAMA, M.; MICHEL, G.P.; GOERL, R.F. Proposal of Debris Flow Disasters Management in Brazil Based on Historical and Legal Aspects. International Journal of Erosion Control Engineering, v. 11, n. 3, p. 85-93, 2019. DOI: 10.13101/ijece.11.85

30. MAGILLIGAN, F. J.; NISLOW, K. H.; FISHER, G. B.; WRIGHT, J.; MACKEY, G.; LASER, M. The geomorphic function and characteristics of large woody debris in low gradient rivers, coastal Maine, USA. Geomorphology, v. 97, n. 3-4, p. 467-82, 2008. DOI: 10.1016/j.geomorph.2007.08.016

31. MARTIN, D. J.; PAVLOWSKY, R. T.; HARDEN, C. P. Reach-scale characterization of large woody debris in a low-gradient, Midwestern U.S.A. river system. Geomorphology, v. 262, p. 91-100, $2016 . \quad$ DOI: 10.1016/j.geomorph.2016.03.005

32. MORENO, J. A. Clima do Rio Grande do Sul. Porto Alegre: Secretaria da Agricultura, 1961. 41p.

33. MORRISSEY, R. C.; JENKINS, M. A.; SAUNDERS, M. R. Accumulation and Connectivity of Coarse Woody Debris in Partial Harvest and Unmanaged Relict Forests. PLoS ONE, v. 9, n. 11, e113323, 2014. DOI: 10.1371/journal.pone.0113323

34. NAKAMURA F.; SWANSON F.J. Distribution of coarse woody debris in a mountain stream, western Cascade Range, Oregon. Canadian Journal of Forest Research, v. 24, n. 12, p. 2395-2403, 1994. DOI: 10.1139/x94-309

35. PAOLA C. Geomorphology: Co-evolution of rivers and plants. Nature Geoscience, v. 4, n. 9, p. 583-584, 2011. DOI: 10.1038/ngeo1247

36. PASTERNACK G.B. Geomorphologist's Guide to Participating in River Rehabilitation. Treatise on Geomorphology, v. 9, p. 843-860, 2013. DOI: 10.1016/B978-0-12-374739-6.00268-2

37. PINTO, C. F.; AGRA, J. U. M.; FURLEY, T. H. F. Uso da madeira de eucalipto na recuperação de rios: Projeto renaturalize. O Papel, v. 78, n. 8, p. 106-113, 2017.

38. RIFFELL, S.; VERSCHUYL, J.; MILLER, D.; WIGLEY, T.B. Biofuel harvests, coarse woody debris, and biodiversity - a meta-analysis. Forest Ecology and Management, v. 261, n. 4, p. 878-887, 2011. DOI: 10.1016/j.foreco.2010.12.021

39. RUIZ-VILLANUEVA, V.; DÍEZ-HERRERO, A.; BALLESTEROS, J.A.; BODOQUE, J.M. Potential large woody debris recruitment due to landslides, bank erosion and floods in mountain basins: a quantitative estimation approach. River Research and Applications, v.30, p.81-97, 2014. DOI: 10.1002/rra.2614

40. SANTOS, R.; ELIAS, G. A.; MARTINS, H. D. B.; PADILHA, P. T.; SOUZA, J. C.; CITADINI-ZANETTE, V. O Furacão Catarina e a Floresta Ombrófila Mista no Parque Nacional de Aparados da Serra, sul do Brasil. Geosul, v. 30, n. 60, p. 109, 2015. DOI: 10.5007/2177-5230.2015v30n60p109 
41. SCHUETT-HAMES, D.; PLUES, A. E.; WARD, J.; FOX, M.; LIGHT, J. TFW Monitoring Program Method Manual for the Large Woody Debris Survey. $1^{\mathrm{a}}$ Ed. Olympia: NW Indian Fisheries Commission, Timber, Fish \& Wildlife, 1999. 66p.

42. STOFFEL, M.; WILFORD, D. J. Hydrogeomorphic processes and vegetation: Disturbance, process histories, dependencies and interactions. Earth Surface Processes and Landforms, v. 37, n. 1, p. 9-22, 2012. DOI: 10.1002/esp.2163

43. USBR and ERDC. National Large Wood Manual: Assessment, Planning, Design, and Maintenance of Large Wood in Fluvial Ecosystems: Restoring Process, Function, and Structure. 2016. 628p + Appendix. Available from: http://www.usbr.gov/pn/

44. WOHL, E.; POLVI, L .E.; CADOL, D. Wood distribution along streams draining old-growth floodplain forests in Congaree National Park, South Carolina, USA. Geomorphology, v. 126, p. 108-120, 2011 DOI:10.1016/j.geomorph.2010.10.035

45. WOHL, E.; BLEDSOE, B. P.; FAUSCH, K. D.; KRAMER, N.; BESTGEN, K. R.; GOOSEFF, M. N. Management of large wood in streams: an overview and proposed framework for hazard evaluation. Journal of the American Water Resources Association, v. 52, n. 2, p. 315-335, 2016. DOI: 10.1111/1752-1688.12388

Esta obra está licenciada com uma Licença Creative Commons Atribuição 4.0 Internacional (http://creativecommons.org/licenses/by/4.0/) - CC BY. Esta licença permite que outros distribuam, remixem, adaptem e criem a partir do seu trabalho, mesmo para fins comerciais, desde que lhe atribuam o devido crédito pela criação original. 